\title{
Redefining the New Public Management and Effects of Indicators: Sustainable Healthcare Mobility
}

\author{
Maura Campra ${ }^{1}$, Silvana Secinaro ${ }^{2}$, Valerio Brescia ${ }^{1} \&$ Cristina Gonçalves Góis ${ }^{3}$ \\ ${ }^{1}$ Department of Economics and Business Studies, University of Piemonte Orientale “Amedeo Avogadro”, Novara \\ (NO), Italy \\ ${ }^{2}$ Department of Management, University of Turin, Torino (TO), Italy \\ ${ }^{3}$ Coimbra Business School, Polytechnic Institute of Coimbra, Coimbra, Portugal \\ Correspondence: Silvana Secinaro, Department of Management, University of Turin, C.so Unione Sovietica, 218 \\ bis, 10134, Torino (TO), Italy. E-mail: valerio.brescia@unito.it
}

Received: March 26, $2019 \quad$ Accepted: April 20,2019 Online Published: May 24, 2019
doi:10.5539/jms.v9n1p141

\begin{abstract}
New Public Management has changed the way we perceive and at the same time govern public health companies. The applied method is quantitative subjective, the theory of New Public Management is redefined. The carried-out elaboration, after having identified the variables considered and the possible mathematical relationship between variables (for example a synthetic index of mobility), defines the relationship between them through linear regression and multivariate statistical analysis. The choice of mobility for acute performance in the ordinary regime between regions in Italy is used as a case study. The challenge of the new millennium is the identification of non-economic indicators useful to support the traditional economic indicators that are not always representative of the real welfare of the population in a modern redefinition of New Public Management approach.
\end{abstract}

Keywords: NPM, healthcare mobility index, social index

\section{Introduction}

\subsection{Criticism and Redefinition of NPM in New Era}

The corporatization of public bodies is part of a process launched in Europe between the 80s and 90s aimed at answering to the new requirements of public spending's rationalization. This process is identified in the literature as New Public Management (NPM) and corresponds to the collection of management and leadership practices gradually introduced in the public sector. NPM is a generic term for a variety of management ideas, often borrowed from the private sector, which introduces ideas and tools such as competition, privatization, management by objectives, decentralization, etc. in the public sector (Hood, 1991, 1995).

The new approach linked to NPM derives from a current aimed at reinventing the government (Osborne \& Gaebler, 1992). Going to analyze the effects to date we are faced with several problems related to the NPM approach. The application of the new paradigm has developed with a series of solutions aimed at improving without a shared basic theory (Osborne \& Gaebler, 1992; Osborne a\& Plastrik, 2000). Most of the activities focused on overcoming the inefficiency and irresponsibility of public administrations linked to performance. Osborne and Gabler (1992) have identified several actions essential for real change, these focus on the responsibility of the government and analysis of the repercussions of their actions, increasing the role of the citizen in the exercise of self-government activities with the maximization of citizen involvement in order to maximize results, overcoming the idea that the citizen is a mere passive customer. The involvement of the citizen in the production with the definition of the budget cycle based on objectives, mission, and results with evaluation of performance linked to costs. All these actions focused on five principles in a single implementation plan: core, consequences, customer, control, and culture (Osborne \& Plastrik, 2000). In the analysis carried out, we will focus only on the role of the citizen, who through the choice of services and his perception given by some specific tools, is able to independently carry out a management control (Osborne \& Gaebler, 1992, p. 73). The ineffectiveness linked to the real ability to collect the input of the service and needs by the citizen currently requires a review and review of the approach to NPM (Dunleavy \& Hood, 1994; Dunn \& Miller, 2007; Dunleavy 
et al., 2005). The change brought by IT and access to information has led to a cognitive, organizational, political and cultural change (Accenture, 2004; Fountain, 2001; Jupp, 2003; Lawson, 1998; Alexander \& Pal, 1998; Heek \& Davies, 1999, Biancone et al., 2019) that must be redefined following the introduction of new tools available and new controlling public projects. The introduction of new information and control tools useful for a better definition of needs and budget has been made necessary by the reduction of resources. The study intends to verify two hypotheses:

HP1: Some social indicators allow public governance to predict the choices of citizens and will enable us to allocate the available resources better.

HP2: the citizen is able, in part thanks to the new tools available, partly thanks to other qualitative and economic variables, to increase his decision-making capacity.

\subsection{Healthcare Stakeholder and NPM}

The NPM movement has its origins in a critique of the traditional way of exercising control and management of public organizations as a requirement for greater efficiency in the public sector. Using the tools developed in the private sector to manage public affairs is possible through the implementation of a communication path aimed at all stakeholders and, in particular, at citizenship. In the public sector, information and communication are made possible through reporting and budgeting tools (Biancone et al., 2016). An organization can have many stakeholders and, consequently, a wide range of actual or potential users of financial reporting. The approach to stakeholders' spreads in the 80 s considers the corporate choices not only aimed at maximizing shareholders but also for the maximum benefit of the community, not only economic but for all those who have a relationship with the company. Stakeholders are defined, in the first definition, as groups which would cease to exist without the organization (Freeman \& Reed, 1983). In the public shareholder and specifically in health companies, the citizen is the subject interested in reaching and satisfying the needs. The involvement of all the stakeholders must create a mapping of the interesting parts, the top management in the company governance is required to involve both the passive and the active stakeholders in the decisions (Freeman et al., 2007). The theory based on the rights of the different stakeholders focuses attention on all those groups that might have an interest in the provision of the service (Mitchel et al., 1997). The main users of the health service are citizens, who in a new perspective of public companies answer to the need by providing useful and essential information for the production, becoming themselves producers of the service. Co-production does not merely involve bilateral relations, and there are multiple relationships between health service customers and other stakeholders. The citizen holds the role of legitimator and authority, defines through public processes the public value attributable to the service, directs policies and has the ability to create public value (Bryson et al., 2017). In the health service, Hyde and Davies (2004) found a complex interaction between organizational design and customer interactions that co-produces care through a series of relationships. Co-production by users and communities has provided an important integration mechanism, bringing together a wide variety of stakeholders in the public interest, frequently ignored and usually underestimated in its potential to increase the effectiveness of service delivery policies. This framework suggests the need to recontextualize the provision of services as a process of social construction in which the actors of self-organizing systems negotiate rules, norms and institutional frameworks rather than taking the rules of the game as given (Bovaird, 2007). In company planning, access to information by the user could be a key element for the definition of the financing of services and the level of the output of the company. Eysenbach and Jadad (2001) hypothesize that decisions and care choices are possible for patients through the use of the Internet, obtaining clinical information on performance and online results is seen as sufficient factor to guide the choice with respect to the doctor or the most appropriate medicines, however, there is no evidence on the actual choice of the patient with respect to the progress of the health system. Other authors have shown that the availability of information is not sufficient to guide the choice and that there is an information asymmetry between the information that the user has and the choice of treatment (Bloom et al., 2008). The citizen often approaches public management only when needed and is not aware of all the services provided, of the quality of services and of the capacity of the health service to answer to the need in each region (Pica \& Villani, 2010). The theory linked to the type of information useful to guide the planning of the health care company has not yet thoroughly analyzed how much information and indicators available to the main stakeholders can affect the service and the choices of production and company governance. The NPM has sometimes brought positive social impacts on problem-solving, other times the change and innovation have had unexpected changes in democratic countries, in Figure 1 it is possible to identify the relationship given by the approach (Becker, 1985). However, often the reforms and policies implemented do not take into account the indirect effects (Hood \& Peters, 2004). 


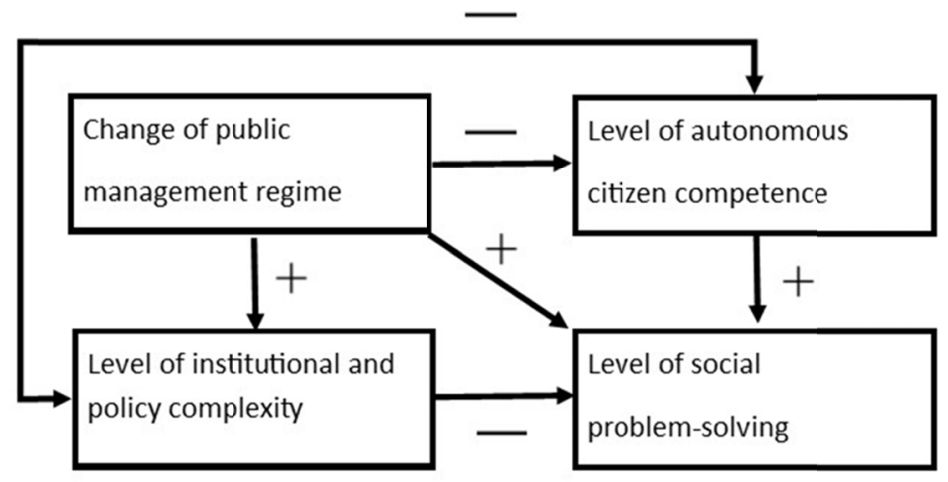

Figure 1. Mapping the direct and by-product effects of changes in public management regimes

Source: Becker, 1985.

The relationship between the four elements illustrates some essential elements for understanding the NPM-related paradox. In particular, citizens and their level of expertise positively influence the resolution of social problems. The complexity of the institutional level and policies negatively affect the level of social problem-solving. The change in public or management linked to reforms decreases the level of competence of the citizen and increases the difficulty in solving problems. The approach questioned analyses what tools could influence management overturning governance and influencing the model. The New Policy can be defined through specific corrective actions given by the new information systems useful for the programming of resources based on the perception of the population and the objective indicators available. The tools we are going to analyze have an impact on the highlighted model.

\section{Materials and Method}

\subsection{Method}

The conducted analysis is quantitative subjective, and the theory is demonstrated through the focus of a real case in order to increase the understanding of theoretical assumptions (Burrell \& Morgan, 1979) and defining the change of managerial and organizational approach (Burns, 2000; Burns \& Scapens, 2000). The carried-out elaboration, after having identified the variables considered and the possible mathematical relationship between variables (for example a synthetic index of mobility), defines the relationship between them through linear regression and multivariate statistical analysis. All analyses were verified with a robustness test that confirms the significance of the relationships. All statistical analyses were performed using STATA V.13 (Stata Corp, College Station, Texas, USA, 2013) and p-value $<0.05$ was considered significant for all analyses. The case study takes into account data on regional mobility in Italy in 2014, 2015, 2016, the welfare indicators of the "BES" project for the years 2015, 2016, 2017, data provided by the ISTAT platform "Health for all" on economic variables (GDP), population and mortality index, and finally the LEA indicators defined by the Ministry of Health of Italy for 2014 and 2015.

\subsection{Used Variables}

\subsubsection{Accountability and Sustainability Through Social Indicators}

In recent years, scholars and operators compare the different health systems, paying attention to increasing national and regional needs. In particular, a debate has developed around the technical efficiency of health policies, understood as the ability of public policies to pursue quality health performance by making the best use of available resources (Retzlaff-Roberts et al., 2004). With the economic crisis of 2008, the descriptive and interpretative efforts of the various health systems increased dramatically, also in comparative terms (Levy \& Sobolev, 2016). The scarcity of available resources and the consequent cuts in public spending, indeed, have raised the question of the model and type of health, in the legitimate attempt to identify the institutional structures and production solutions comparatively more efficient than the others, also concerning the system outcomes. For a couple of decades, economists, sociologists, and psychologists have been working together to develop indexes that reflect the quality of life developments better than GDP statistics. "Happiness formulas" were also invented by combining various criteria of welfare measurement with measures of subjective perception of individuals about their situation. During this period there has been a much theoretical concern for the study of 
the competitiveness exercised by experts and international bodies by experts from the academic sector and consulting businesses. Most of these studies describe the main determinants of economic performance on competitiveness and the interdependence between a country's current socio-economic development and its potential growth. Gross domestic product is the most widely used indicator in the measure of economic activity but has numerous flaws. It is able to measure only market production, without recourse to market prices, and does not take into account consumer surplus or produced externalities. The current recession did not happen because we could not follow the kind of advice given by this Commission; the current recession took place for a cyclical process that is part of the nature of the economic system (Leunig, 2011). The European Observatory on health systems and policies has published studies that are more complete and methodologically based on comparative analysis, both on the functioning of health systems and the reforms and political initiatives started or underway in the European countries belonging to the World Health Organization. For its part, in 2008, the Organization for Economic Cooperation and Development (OECD) promoted a sciential survey on governance systems and decision-making, responsibilities and financial resources available in the various OECD countries. (Paris et al., 2010). It is also to be considered that the creation of too many indexes by the created commission could make the relationship not interpretable and not general, returning the role of the main indicator of comparison to GDP. The Commission's report on the measurement of economic performance and social progress is vaguely interesting but offers little regarding historical economic value. It does not give alternatives over time as the different companies have implemented the shares based on the different indexes. It is estimated that, taken as a whole, changes in per capita GDP may overestimate or underestimate economic performance and social progress, or that this measure is more or less accurate for different countries or different periods. Indicators and composite indexes are increasingly recognized as useful tools for policies because they bring information about a country's performance (Landry et al., 1999). The main advantage of an indicator is its ability to synthesize complex information from our dynamic world into a manageable amount of meaningful information. Some scholars claim that there are no ideal planning tools to achieve sustainability either on a regional or local scale (Keiner, 2006). Recently, politicians have begun to encourage scientists to improve models and develop new techniques to integrate quantitative and qualitative analysis for local and regional planning of sustainable development (Grosskurth \& Rotmans, 2007). In particular, the correct choice of indicators is essential to monitor progress towards sustainable territorial development. Accountability is one of the results of NPM and involves those who perform a function of planning, management or control, as a responsible subject towards those who accept the effects of the exercise of these functions (Ricci, 2005). NPM and New Public Management increasingly increase the need for transparency, the citizen wants to know and wants to decide services, but in the health, sector is not sure whether he/she is able to perceive and choose by the information at his/her disposal. About a territory, if it is reported, it is because there are subjects to whom account must be given and, at the same time, there are some subjects who feel the need and the responsibility to report on the actions taken. The social responsibility of the territory is an approach to development that is being imposed in the search for sustainable models on a global scale. The social sphere is at the centre in its widest and most complete meaning, including and exceeding the economic categories and the needs of profit.

\subsubsection{Bes and Social Indicators}

BES is the project to measure fair and sustainable wellness, is part of the international debate on overcoming the GDP, fuelled by the awareness that the parameters on which to evaluate the progress of a company cannot be exclusively economic but must also take into account the fundamental social and environmental dimensions of well-being, accompanied by measures of inequality and sustainability. The document was presented in its fifth edition on December 15th, 2017. BES (Fair and Sustainable Wellness) is based largely on the OECD framework. It represents a demanding challenge in this document because it seeks to integrate wellness with equity and sustainability. This involves significant theoretical problems that need to be clarified and resolved before the technical, methodological discussion can be started on how to measure the dimensions present in the various domains. Bes is a process that takes the multidimensionality of wellness as a starting point and, through the analysis of a large number of indicators, describes all the aspects that contribute to the quality of life of citizens. In this context, official statistics must keep up with the growing demand for statistical information of quality. It is then up to citizens and their representatives to choose which dimensions of wellness are able to return more value and on which it is opportune to invest, with the awareness that the achievement of some objectives could compromise or delay the achievement of others. Bes can also assist the public administration in the decision-making process and at the same time provide the citizen with information that guarantees transparency and a reading key also linked to the services that the company offers. It is important the influence that the community and the level of public acceptance have on social indicators and therefore on the possibility of using them for comparison (Jones et al., 2012, Gutierrez et al., 2011). The functions of the public company can, 
therefore, be representative on an aggregated level both in quantitative and qualitative terms of achievement of the programmed results and through comparison and a key of interpretation as regional statistical indicators of reference on specific activities. In a complex system, it is necessary to look for common reading keys and broad indicators that allow understanding of the work of Governance, Culture and the Economy of a territory. In our analysis it is possible to consider the 2015 health compound indicator as an effect of the 2014 financial year to assess the perception of health, the same indicator is also present for the year 2016 as an effect of the perception of 2015 while it is not possible comparison with the third year of 2017 as ISTAT preferred not to make this indicator more explicit as a reference to the health perception trend, replacing it with a series of objective measurement indicators. Among the indicators used to evaluate the perception of the different regions also the composite of education and training, the composite of income and social inequality, the composite of unease, the composite on social relations, the trust in other types of institutions (territorial health and public bodies), the rate of innovation and product of the service on the productive system and the difficulty of access to some services. In 2017 the composite indicators are reduced not allowing an appropriate comparison, although the analysis is still conducted, it is also reported that others replace some indicators. The social indicators BES are both objective and subjective type. The first is based on the objective quantitative evaluation with a ratio between quantitative factors. The second is qualitatively based on the survey, in this case, it is a question of non-objective variables but represents the evaluation of users. Both in 2014 and 2015, the number of residents and per capita GDP can be assessed. In the two years through another ISTAT project called "Health for all Italy", database of indicators on the health and health system in Italy, structured in such a way as to be interrogated by the HFA software provided by the World Health Organization adapted to national needs, it is also possible to evaluate the mortality indicator as an objective indicator of evaluation of health services for each region. The data for 2017, unfortunately, both on the per capita GDP per region and as regards the mortality rate are not yet available; therefore, only the data useful for the analysis are represented. The indicators and data available for each year can be identified in Table 1, Table 2 and Table 3 for quick representation and are made up of observable objective variables and subjective variables based on the perception of residents as the perception of wellness (health). The empty boxes in the tables represent the missing data for the BES indicators or not yet available for the other values because not processed by the national statistical service. The indicators and tools used are placed in the international discussion thanks to projects of assessment of governance, accountability and perception by similar stakeholders such as the use of indicators to assess the perception of health, mortality, wealth of families, indicator composed of quality of the service provided in the OECD countries (Biancone et al., 2018). The variables analyzed are present in the appendix (Table 1. Mobility and variables for 2014; Table 2. Mobility and variables year 2015; Table 3. Mobility and variables for 2016).

\subsubsection{Planning and Health Systems and Lea}

Healthcare funding policy is an integral part of efforts to move to UHC (universal health coverage), but to align health financing policy with UHC prosecution, health care reforms need to be explicitly targeted to improve coverage and the intermediate objectives related to it, that is, efficiency, fairness in the distribution of health resources and transparency and accountability. The unit of analysis by objectives and the objective itself must be the population and the health system as a whole. What matters is not the way in which a particular funding scheme affects its members, but rather how it influences progress towards UHC at the population level. The systematic approach goes through the System expressed in Figure 2 (World Health Organization, 2010), where the objectives expressed influence the planning, programming, and control starting from the consideration of need, efficiency, quality, transparency, and accountability. All the elements expressed in the graph are considered in the management and preparation of the funding and the control of production business flows. The key performance indicators represent the achievement of results in healthcare companies and are configurable as the capacity and the level of answer to a need. 


\section{Health system functions \\ Intermediate objectives of health finance policy \\ Health system \\ goals}

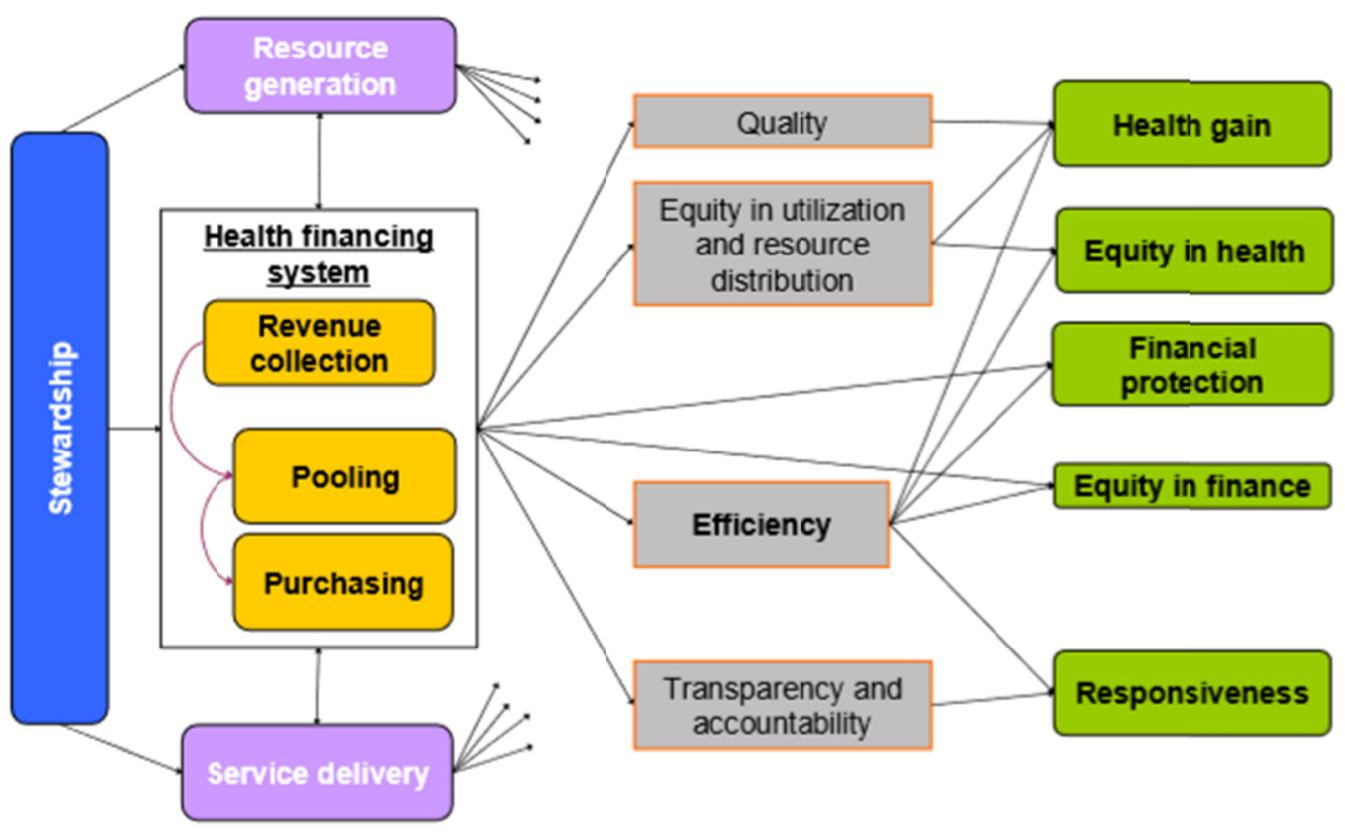

Figure 2. Health system goals and health financing policy objectives (Kutzin, 2008)

In Italy, the complex system of financing health services depends partly on the funding provided by the National Health Fund and partly on own regional revenues. Funding based on per capita share, based on inhabitants, must ensure a balance between available resources and the provision of adequate health services through the essential levels of assistance (LEA, Bernardi \& Pegoraro, 2003). The Regions, as they have done up to now, will be able to guarantee additional services and services compared to those included in the LEAs, using their own resources. LEAs are by current health planning in Italy and are grouped into three major levels: collective prevention and public health, district assistance, and hospital assistance. The certification of fulfilments takes place through the documentation required explicitly to the regions through a questionnaire and an analysis of the same integrated with information already available at the Ministry of Health. Certification is carried out by the members of the LEA Committee which also establish compliance and criteria for assessing the fulfillment or non-fulfillment of the regions. The preliminary work is conducted by the offices of the Ministry responsible for matters of compliance, examined and validated by the members of the LEA Committee. An interactive comparison with the regional representatives is foreseen. Specifically, the certification of the fulfillment of the "maintenance in the provision of LEAs" area occurs through the use of a defined set of indicators divided between the three large levels. The regions are placed in the compliance class if the score obtained is $\geqslant 160$ or between 140-160 and no critical indicator while it will be placed in the default class if the score obtained is $<140$ or between $140-160$ with at least one critical indicator. In our analysis, we will not give evidence of the criticality of each region, but we will use Lea as a representative indicator of the objective quality of performance of each region to other variables, evaluating the relationship and the trend. It is possible to evaluate for 2014 and 2015 only the Leas of the Italian regions with the ordinary statute.

\subsection{Inter-Regional Health Mobility and Its Financial Implications}

Healthcare planning must take into account the effectiveness of the service and the implications produced on the LEA, regarding governance and accountability, health mobility is a phenomenon that must be taken into account. Health migration is the movement of patients from the regional territories of residence to other areas considered more equipped from the diagnostic and therapeutic point of view, in order to obtain better assistance. The phenomenon of health mobility is present not only in Italy but also in other countries of the European community and the United States of America. The principle of free choice, by patients, of the place where receiving care to which they are entitled has transformed since 1992 the Italian Health System. The topic 
concerns both the management of the services in the Health Authorities and those involved in planning at the level of local authorities and, therefore, it needs to obtain adequate information on the level of needs to be met and on accessibility to local public services.

Moreover, the transfers of the assisted people among the health services structures of the Regions imply the need to regulate the debit and credit positions for the rates in force for each service. The National Healthcare Fund, which distributes on a share capital, defines through the Ministry of Health the services to be taken into consideration, the characteristics of the information flow (tracked records), the times and methods of data transmission, the system to check the charges transmitted, the procedures for contestation and those provided for the initiation of counter-deductions. The classification of the services is currently carried out using the International Classification of Diseases system, in order to standardize the Grouped CMS ICD-9-CM classification system. For the proposed analysis, the information obtained from the SDO database was used, i.e., the national database on hospital admissions, set up at the Ministry of Health and freely available online, which includes information on all admissions. It is registered in Italy since 1996. Both in Table 1 and Table 2 and Table 3 it is possible to deepen the analysis by studying the escape and attraction indexes of the individual regions. The proposed method is applicable internationally. The national average value can be assumed as a reference value to evaluate the trend. The synthetic mobility index (ISM) can be calculated as the ratio between the attraction index and the escape index. The ISM always assumes values greater than or equal to zero. It is zero when the attraction is null, that is when in the considered catchment area, no non-resident admissions were made. Values between 0 and 1 indicate inter-regional immigration lower than emigration. Values greater than 1 are when the incoming flows exceed the output flows. On an exemplary level, for statistical significance, the values that represent the mobility for the acute in the ordinary regime were observed. The synthetic mobility index will be one of the variables used to evaluate the choice of the citizen and the relationship with other regional, economic and qualitative variables of respect for the essential assistance levels.

\section{Statistical Analysis Results}

For both the year 2014 and 2015 the combined health index and the relative perception of health in each region increases as the per capita GDP increases, the dependency variable is the health compound index (2014 standard) error $=1,332$, $\mathrm{p}$ value $<0.001$ and $\mathrm{R} 2=0.7735$, year 2015 standard error $=1.709$, $\mathrm{p}$ value $<0.001, \mathrm{R} 2=0.6626$ ) For both 2014 and 2015 the synthetic mobility index decreases with the difficulty of access to services, the dependent variable is the synthetic mobility index (2014 standard error $=0.456$, $\mathrm{p}$ value $=0.011$ and $\mathrm{R} 2=0.307$; 2015 standard error $=0.0500$, $\mathrm{p}$ value $=0.014, \mathrm{R} 2=0.2903$ ). In 2014 and 2015 the compound health index, and the relative health perception increases with the rise in the number of LEA reached in each region, the health compound index is the dependent variable (year 2014 standard error $=0.051$, $\mathrm{p}$ value $<0.001$ and $\mathrm{R} 2=0.714$; 2015 standard error $=0.0366$, p value $<0.001, \mathrm{R} 2=0.778$ ). For both 2014 and 2015 there is a positive correlation between the synthetic mobility index and the perception of health, the synthetic mobility index is the dependent variable (2014 standard error $=0.014$, $p$ value $=0.001$ and $R 2=0.439,2015$ standard error $=0.014, p$ value $=0.005, \mathrm{R} 2=0.358$ ). For both 2014 and 2015, the LEAs achieved in each region increase as the per capita GDP increases, the Lea are the dependent variable ( 2014 standard error $=6.142$, $\mathrm{p}$ value $=0.001$ and $\mathrm{R} 2=0.558$; 2015 standard error $=6.609$, $\mathrm{p}$ value $<0.001, \mathrm{R} 2=0.664$ ). For both 2014,2015 and 2016 , there is no correlation between mobility and the overall perception of each region using the different composite indicators available as independent variables with respect to the dependent variable mobility $(p>0.05)$. There is no correlation between mortality indicator and health perception, just as there is no correlation between perceived quality, perception and achievement of LEA. The results are summarized in Table 4.

Table 4. Relationship between varables

\begin{tabular}{lllll}
\hline Dependent variable & Effect & Independent variable & P value & R2 \\
\hline 2014 BES helth index $=$ perception of health & + & per capita GDP & $<0.001$ & 0.7735 \\
2015 BES helth index = perception of health & + & per Capita GDP & $<0.001$ & 0.6626 \\
2014 mobility index & - & BES difficulty of access to services & 0.011 & 0.307 \\
2015 mobility index & - & BES difficulty of access to services & 0.014 & 0.2903 \\
2014 BES helth index = perception of health & + & LEA reached in each region & $<0.001$ & 0.714 \\
2015 BES helth index = perception of health & + & LEA reached in each region & $<0.001$ & 0.778 \\
2014 BES helth index $=$ perception of health & + & synthetic mobility index & 0.001 & 0.439 \\
2014 BES helth index = perception of health & + & synthetic mobility index & 0.014 & 0.005 \\
2014 LEAs achieved in each region & + & per capita GDP & 0.001 & 0.558 \\
2015 LEAs achieved in each region & + & per capita GDP & $<0.001$ & 0.664 \\
\hline
\end{tabular}




\section{Discussion}

The Italian state, as well as other countries, have been engaged for a long time in the definition of a series of social indicators aimed at measuring the perception and satisfaction of the needs of citizens. The post-industrial 21 st-century perspective focuses on the assessment of well-being aimed at answering to needs, rather than focusing on level and production growth. From 1960 to today several studies have been done on the subject (Land, 2012; Glatzer et al., 2015; Hagerty \& Land, 2001; Volger, 1999; Cramm et al., 2012; Andrews et al., 2015). In Italy the introduction of BES project: the fair and sustainable well-being that has taken place since 2014 by ISTAT CNEL and ISTAT guarantees some reference indicators at the national level (Biancone et al., 2018; Biancone et al., 2018c). The indicators provided in Bes report aim to make the country more aware of its strengths and difficulties to overcome in order to improve the quality of life of its citizens, placing this concept at the base of public policies and individual choices (Biancone et al., 2017; Brescia, 2019). In Italy the Ministry of Health has defined an Essential Assistance Level (LEA) that represents the provisions and services that the National Health Service (NHS) is required to provide to all citizens, free of charge or upon payment of a participation fee (ticket), with public resources collected through general taxation (taxes) and which can represent the capacity of each region to answer to the needs of the resident population (Brescia et al., 2017). Planning and programming the expenditure and the volume of services to be provided is not easy in a system where the economic crisis reduces the available resources. The obtained results show that various information could direct and influence the choices of the stakeholders, affecting the governance choices of the healthcare companies. The corporate social responsibility and accountability provide as a priority element the involvement of stakeholders and in particular in the public community and citizens (Jones et al., 2007; Mohammed, 2013). The economic evaluation has not yet been completely overcome as this could still influence the other variables at stake. The social indicators associated with objective indicators of achievement of minimum performance and GDP trends are all elements to be taken into consideration. The population from the first statistical analyses could be affected by the per capita GDP available in the perception of overall health, but it seems to be aware of the real performance of the number of essential services provided (LEA) during health mobility choices for acute performance in the ordinary regime. Just as in the attractiveness given by each region in tourism companies, even in healthcare mobility, GDP influences the choice with a direct impact on perception and relapse (Alonso-Almeida et al., 2016), but it is always necessary to consider several indirect variables, identifying the most appropriate analysis mediators. The degree of satisfaction as in private companies is also important in public companies but should not be used alone to read the results but must always be associated with objective indicators. The monitoring of access to public services and the collection of information is necessary for real-time to obtain results that are always up to date and ready to direct choices. It has been shown that the exchange of information also on the quality of services helps both to change perceptions and to increase the reading capacity of stakeholders end politicians (Glatzer, 2015; Kundu \& Datta, 2015; AL Athmay et al., 2016). Furthermore, it seems to be able to direct the choice of active mobility by the ease of access to public administration services without taking into account the trend and the general perception given by the regional indicators of the different regions. The use of information and communication technologies in the healthcare sector offers great potential, but many data and indicators have not yet been fully used and put into the system (Aggelidis \& Chatzoglou, 2008). The aging of the global population and the reduction of available resources requires public health to better orientate intervention choices and resources according to the needs of each region to increase the sustainable use of resources (Adderley \& Mellor, 2014). By analyzing the impact that the new tools have on the mapping of the elements involved in the NPM Figure 1 approach, some important considerations can be made. The indicator composed of the perception of the difficulty of access to services and the relative level of mobility between the regions shows us the real perception of the citizen of the situation. Specific indicators of social impact (BES), positively affect the level of autonomous citizen competence. The same effect is attributable to the level of LEA respected. In turn, per capita income positively affects both the LEA level and the specific social impact indicators (BES). Therefore, analyzing the social problem of healthcare mobility, it is possible to propose an integration to the NPM model in healthcare linked to the new tools in Figure 3. 


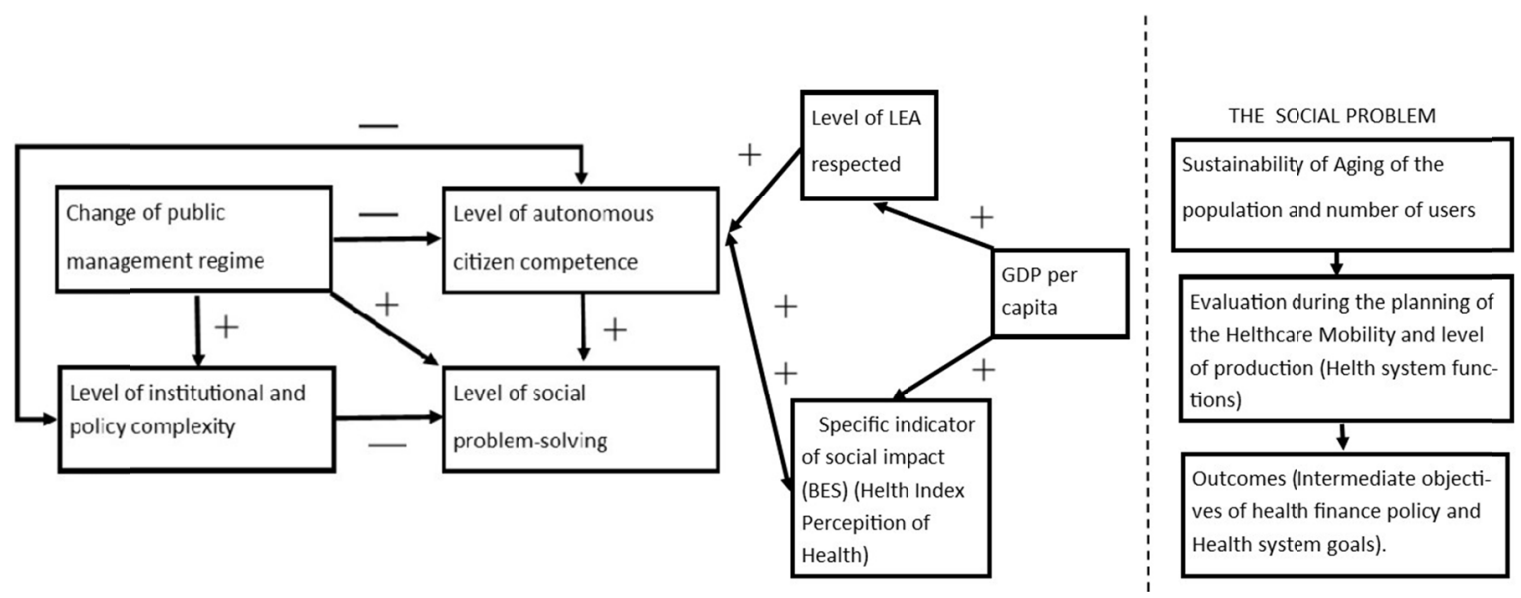

Figure 3. Mapping direct and by-production effect of changes in public management regimes and the new social and quality tools in healthcare

The effect and impact of the new instruments on the change of public management regime and the complexity of policies are not yet known. Over time, the development of new control systems and indicators has complicated institutional management, however, leading to a positive parallel effect on the level and competence of citizens' citizens by strengthening the positive relationship linked to the resolution of social problems. The level of competence related to the knowledge of citizens and their awareness of indicators and trends and specific social issues is closely linked to the possession of the internet and use in the information process (Biancone et al., 2018a). On the other hand, the use of ICTs systems based on innovation capacity, open innovation, developing knowledge management system could allow an increase in the external and internal knowledge management processes facilitating management decisions.

\section{Conclusions}

A planning and control system based on social welfare indicators, associated with the economic performance represented by per capita GDP and the level of essential services provided could be useful indicators to guide the governance of the health system and at the same time, which information is useful to meet the needs of NPM represented by a growing need for transparency and accountability of the population and other stakeholders. The challenge of the new millennium is the identification of non-financial indicators useful to support the classic financial indicators that are not always representative of the real welfare of the population, and not always easy to understand for everyone. The study conducted increases and integrates the Becker theory (1985), identifying the effect of some innovative variables adopted in reality on the model. The study of the positive and negative effects of some project outputs in healthcare is useful for identifying possible solutions to increase the level of autonomy and citizenship, thus providing useful tools to reduce the critical aspects of NPM. Better planning and management of expenditure that takes into account more indicators allow rationalization of the resources used towards real citizens' satisfaction, also considering the need to respond to more and more users in the healthcare sector. The diffusion of all indicators that are easy to understand could allow greater perception by orienting choices and reducing the information asymmetry that is often present between the consumer and the public company (Waterman \& Meier, 1998). Citizens who are satisfied concerning information are able to legitimize managerial and political decisions and guide spending through decision-making (Irvin \& Stansbury, 2004; Yusuf et al., 2013). The mapping of flows between variables of the Public Management model highlights the presence of an exchange between the capacity of the citizen and assessment of reality through the new project linked to social indicators, allowing more significant information and transparency through the attainment of quantitative, qualitative levels and well-being between citizens (indicators LEA). However, the analyzed approach and the indicators identified continue to be conditioned by the economic aspect that influences the whole approach. Citizens very often underestimate the cost of the service (Benito \& Bastida, 2009) and politicians prefer not to provide detailed information because they are afraid of the effects of transparency (Jordan et al., 2017). A greater focus on political outcomes could affect the vote. Therefore, political action often negatively influences the dissemination of transparency tools and knowledge of the citizen, sometimes increasing the institutional complexity and varying the public management regime. Future research could be based on the effect of the dissemination of transparency indicators, through communication tools to the citizen, on the change public 
management regime and the complexity of policies. The conclusions, strengths, and weaknesses highlight the actual impact in theoretical and practical terms of the analysis conducted.

\subsection{Strengths and Limitations of the Current Study}

The study is innovative, and no similar studies have been conducted. The use of non-financial information is suggested by the European community to better involve all stakeholders, Directive 2014/95/ EU (EU, 2014). The obsolescence of data gives the possible limitation of the proposed model at the time of use by politicians and legislators. The study is conducted on Italian indicators, and it is important the reproduction and analysis in other countries in which financial, non-financial and social indicators have already been developed. Some studies on the relationship between the European Better life index project, economic factors, and objective quality indicators have already been carried out on the OECD countries (Biancone et al., 2018b).

\section{References}

Adderley, S., \& Mellor, D. (2014). Who's influencing whom? Developing sustainable business partnerships. EuroMed Journal of Business, 9(1), 60-74. https://doi.org/10.1108/EMJB-06-2013-0033

Aggelidis, V. P., \& Chatzoglou, P. D. (2008). Methods for evaluating hospital information systems: a literature review. EuroMed Journal of Business, 3(1), 99-118. https://doi.org/10.1108/14502190810873849

AL Athmay, A. A. A., Fantazy, K., \& Kumar, V. (2016). E-government adoption and user's satisfaction: an empirical investigation. EuroMed Journal of Business, 11(1), 57-83. https://doi.org/10.1108/EMJB-05-2014-0016

Alonso-Almeida, M. D. M., Llach, J., Barquero, J. D., \& Bremser, K. (2016). Workforce and destination influence over hospitality industry performance. EuroMed Journal of Business, 11(3), 403-417. https://doi.org/10.1108/EMJB-04-2016-0014

Anderson, R. E. (2016). World suffering and quality of life. Berlin: Springer.

Benito, B., \& Bastida, F. (2009). Budget transparency, fiscal performance, and political turnout: An international approach. Public Administration Review, 69(3), 403-417. https://doi.org/10.1111/j.1540-6210.2009.01988.x

Bernardi, A., \& Pegoraro, R. (2003). Italian drug policy: ethical aims of essential assistance levels. Health Care Analysis, 11(4), 279-286. https://doi.org/10.1023/B:HCAN.0000010056.05684.22

Bernstein, T. B. (1977). A modern guide to English usage (2nd ed.). New York, NY: Atheneum.

Biancone, P., Silvana, S., \& Valerio, B. (2016). Popular report and Consolidated Financial Statements in public utilities. Different tools to inform the citizens, a long journey of the transparency. International Journal of Business and Social Science, 7(1), 111-124.

Biancone, P. P., Secinaro, S., \& Brescia, V. (2017). Popular financial reporting: Results, expense and welfare markers. African Journal of Business Management, 11(18), 491-501. https://doi.org/10.5897/AJBM2017.8367

Biancone, P. P., Secinaro, S., \& Brescia, V. (2018). The accounting innovation by welfare indicators. Economia Aziendale Online, 9(2), 127-174.

Biancone, P. P., Secinaro, S., Brescia, V., \& Iannaci, D. (2018a). Communication and Data Processing in Local Public Group: Transparency and Accountability. International Journal of Business and Management, 13(10). https://doi.org/10.5539/ijbm.v13n10p20

Biancone, P. P., Silvana, S., \& Valerio, B. (2018b). Better Life Index and Health Care Quality Indicators, Two New Instruments to Evaluate the Healthcare System. International Journal of Business and Management, 13(2), 29-39. https://doi.org/10.5539/ijbm.v13n2p29

Biancone, P., Secinaro, S., \& Brescia, V. (2018c). A Planning and Control System Based on Social Welfare Indicators Useful Way to Guide the Governance for Sustainable Healthcare Mobility (pp. 158-176). In 11th Annual Conference of the EuroMed Academy of Business. Demetris Vrontis, Yaakov Weber, Evangelos Tsoukatos.

Biancone, P. P., Secinaro, S., Brescia, V., \& Calandra, D. (2019). Data Quality Methods and Applications in Health Care System: A Systematic Literature Review. International Journal of Business and Management, 14(4). https://doi.org/10.5539/ijbm.v14n4p35

Bjork, R. A. (1989). Retrieval inhibition as an adaptive mechanism in human memory. In H. L. Roediger III \& F. I. M. Craik (Eds.), Varieties of memory \& consciousness (pp. 309-330). Hillsdale, NJ: Erlbaum. 
Bloom, G., Standing, H., \& Lloyd, R. (2008). Markets, information asymmetry and health care: towards new social contracts. Social Science \& Medicine, 66(10), 2076-2087. https://doi.org/10.1016/j.socscimed.2008.01.034

Bovaird, T. (2007). Beyond engagement and participation: User and community coproduction of public services. Public Administration Review, 67(5), 846-860. https://doi.org/10.1111/j.1540-6210.2007.00773.x

Brescia, V. (2019). The popular financial reporting: new accounting tool for Italian municipalities. FrancoAngeli.

Brescia V., Rainero, C., Secinaro, S., Indelicato, A., Migliavacca, A., Siliquini, R., ... \& Gualano, M. R. (2017). Italian Health Care System: Methodology Suggestion for the Financial Equilibrium and Essential Level of Care. Business, Management and Economics Research, 3(4), 40-51.

Bryson, J., Sancino, A., Benington, J., \& Sørensen, E. (2017). Towards a multi-actor theory of public value co-creation. Public Management Review, 19(5), 640-654. https://doi.org/10.1080/14719037.2016.1192164

Burns, J. (2000). The dynamics od accounting change. Accounting, Auditing and Accountability Journal, 13(5). https://doi.org/10.1108/09513570010353710

Burns, J., \& Scapens, R. (2000). Conceptualizing management accounting change: an institutional framework. Management Accounting Research, 11, 3-25. https://doi.org/10.1006/mare.1999.0119

Burrell, G., \& Morgan, G. (1979). Sociology paradigm and organisational analysis: Elements of the Sociology of Corporate Life.

Clarke, A., \& Craft, J. (2017). The vestiges and vanguards of policy design in a digital context. Canadian Public Administration, 60(4), 476-497. https://doi.org/10.1111/capa.12228

Cramm, J. M., Møller, V., \& Nieboer, A. P. (2012). Individual-and neighbourhood-level indicators of subjective well-being in a small and poor Eastern Cape township: The effect of health, social capital, marital status, and income. Social Indicators Research, 105(3), 581-593. https://doi.org/10.1007/s11205-011-9790-0

Cress, C. M. (2009). Curricular strategies for student success and engaged learning [PowerPoint slides]. Retrieved from http://www.vtcampuscompact.org/2009/TCL_post/presenter_powerpoints /Christine\%20Cress\%20-\%20Curricular\%20Strategies.ppt

Directive, E. U. (2014). Directive 2014/95/EU of the European Parliament and the Council of 22 October 2014 amending Directive 2013/34/EU as regards disclosure of non-financial and diversity information by certain large undertakings and groups. EU L, 330, 1-9.

Driedger, S. D. (1998, April 20). After divorce. Maclean's, 111(16), 38-43.

Dunleavy, P., \& Hood, C. (1994). From old public administration to new public management. Public Money \& Management, 14(3), 9-16. https://doi.org/10.1080/09540969409387823

Dunleavy, P., Margetts, H., Bastow, S., \& Tinkler, J. (2006). New public management is dead-long live digital-era governance. Journal of Public Administration Research and Theory, 16(3), 467-494. https://doi.org/10.1093/jopart/mui057

Dunn, W. N., \& Miller, D. Y. (2007). A critique of the new public management and the neo-Weberian state: advancing a critical theory of administrative reform. Public Organization Review, 7(4), 345-358. https://doi.org/10.1007/s11115-007-0042-3

Eysenbach, G., \& Jadad, A. R. (2001). Evidence-based patient choice and consumer health informatics in the Internet age. Journal of Medical Internet Research, 3(2). https://doi.org/10.2196/jmir.3.2.e19

Freeman, R. E., \& Reed, D. L. (1983). Stockholders and stakeholders: A new perspective on corporate governance. California Management Review, 25(3), 88-106. https://doi.org/10.2307/41165018

Freeman, R. E., Rusconi, G., \& Dorigatti, M. (2007). Teoria degli stakeholder. Franco Angeli, Milano.

Gibbs, J. T., \& Huang, L. N. (Eds.). (1991). Children of color: Psychological interventions with minority youth. San Francisco, CA: Jossey-Bass.

Gilbert, D. G., McClernon, J. F., Rabinovich, N. E., Sugai, C., Plath, L. C., Asgaard, G., ... Botros, N. (2004). Effects of quitting smoking on EEG activation and attention last for more than 31 days and are more severe with stress, dependence, DRD2 A 1 allele, and depressive traits. Nicotine and Tobacco Research, 6, 249267. https://doi.org/10.1080/14622200410001676305 
Glatzer, W. (2015). Worries and pain-The dark side of quality of life. In Global Handbook of Quality of Life (pp. 855-868). Springer, Dordrecht. https://doi.org/10.1007/978-94-017-9178-6_40

Goleman, D. (2009). What makes a leader? In D. Demers (Ed.), AHSC 230: Interpersonal communication and relationships (pp. 47-56). Montreal, Canada: Concordia University Bookstore (Reprinted from Harvard Business Review, 76(6), pp. 93-102, 1998).

Grosskurth, J., \& Rotmans, J. (2007). Qualitative system sustainability index: a new type of sustainability indicator. Sustainability indicators: A scientific assessment, 177-188.

Guignon, C. B. (1998). Existentialism. In E. Craig (Ed.), Routledge encyclopedia of philosophy (Vol. 3, pp. 493502). London, England: Routledge.

Hagerty, M. R., \& Land, K. C. (2007). Constructing summary indices of quality of life: A model for the effect of heterogeneous importance weights. Sociological Methods \& Research, 35(4), 455-496. https://doi.org/10.1177/0049124106292354

Healey, D. (2005). Attention deficit/hyperactivity disorder and creativity: An investigation into their relationship Unpublished doctoral dissertation, University of Canterbury, Christchurch, New Zealand.

Herculano-Houzel, S., Collins, C. E., Wong, P., Kaas, J. H., \& Lent, R. (2008). The basic nonuniformity of the cerebral cortex. Proceedings of the National Academy of Sciences, 105, 12593-12598. https://doi.org/10.1073/pnas.0805417105

Hood, C. (1991). A public management for all seasons? Public Administration, 69(1), 3-19. https://doi.org/10.1111/j.1467-9299.1991.tb00779.x

Hood, C. (1995). The "New Public Management" in the 1980s: variations on a theme. Accounting, Organizations and Society, 20(2-3), 93-109. https://doi.org/10.1016/0361-3682(93)E0001-W

Hyde, P., \& Davies, H. T. (2004). Service design, culture and performance: Collusion and co-production in health care. Human Relations, 57(11), 1407-1426. https://doi.org/10.1177/0018726704049415

Irvin, R. A., \& Stansbury, J. (2004). Citizen participation in decision making: is it worth the effort? Public Administration Review, 64(1), 55-65. https://doi.org/10.1111/j.1540-6210.2004.00346.x

Jones, P., Comfort, D., \& Hillier, D. (2007). Corporate social responsibility: a case study of the top ten global retailers. EuroMed Journal of Business, 2(1), 23-35. https://doi.org/10.1108/14502190710749938

Jordan, M. M., Yusuf, J. E., Berman, M., \& Gilchrist, C. (2017). Popular Financial Reports as Fiscal Transparency Mechanisms: An Assessment Using the Fiscal Transparency Index for the Citizen User. International Journal of Public Administration, 40(8), 625-636. https://doi.org/10.1080/01900692.2016.1186175

Keiner, M. (Ed.). (2006). The future of sustainability. Amsterdam: Springer. https://doi.org/10.1007/1-4020-4908-0

Klimoski, R., \& Palmer, S. (1993). The ADA and the hiring process in organizations. Consulting Psychology Journal: Practice and Research, 45(2), 10-36. https://doi.org/10.1037/1061-4087.45.2.10

Kubrick, S. (Director). (1980). The Shining [Motion picture]. United States: Warner Brothers.

Kundu, S., \& Datta, S. K. (2015). Impact of trust on the relationship of e-service quality and customer satisfaction. EuroMed Journal of Business, 10(1), 21-46. https://doi.org/10.1108/EMJB-10-2013-0053

Kutzin, J. (2008). Health financing for universal coverage and health system performance: concepts and implications for policy. Bull World Health Organ, 91(8), 602-611. https://doi.org/10.2471/BLT.12.113985

Land, K. C. (Ed.). (2012). The well-being of America's children: Developing and improving the child and youth well-being index (Vol. 6). Springer Science \& Business Media.

Landry, R., Amara, N., \& Lamari, M. (2001). Utilization of social science research knowledge in Canada. Research Policy, 30(2), 333-349. https://doi.org/10.1016/S0048-7333(00)00081-0

Leunig, T. (2011). Measuring economic performance and social progress. European Review of Economic History, 15(2), 357-363. https://doi.org/10.1017/S1361491611000086

Levy, A., \& Sobolev, B. (Eds.). (2016). Comparative Effectiveness Research in Health Services. Springer Reference. https://doi.org/10.1007/978-1-4899-7600-0

Liu, S. (2005, May). Defending against business crises with the help of intelligent agent based early warning 
solutions. Paper presented at the Seventh International Conference on Enterprise Information Systems, Miami, FL. Abstract retrieved from http://www.iceis.org/iceis2005/abstracts_2005.htm

MacIntyre, L. (Reporter). (2002, January 23). Scandal of the Century [Television series episode]. In H. Cashore (Producer), The fifth estate. Toronto, Canada: Canadian Broadcasting Corporation.

McLuhan, M. (1970a). Culture is our business. New York, NY: McGraw-Hill.

McLuhan, M. (1970b). From cliche to archetype. New York, NY: Viking Press.

Mellers, B. A. (2000). Choice and the relative pleasure of consequences. Psychological Bulletin, 126, 910-924. https://doi.org/10.1037/0033-2909.126.6.910

Mitchell, R. K., Agle, B. R., \& Wood, D. J. (1997). Toward a theory of stakeholder identification and salience: Defining the principle of who and what really counts. Academy of Management Review, 22(4), 853-886. https://doi.org/10.5465/amr.1997.9711022105

Mohammed, M. (2013). Corporate accountability in the context of sustainability-a conceptual framework. EuroMed Journal of Business, 8(3), 243-254. https://doi.org/10.1108/EMJB-05-2013-0026

Osborne, D., \& Gaebler, T. (1992). Reinvesting government: How the entrepreneurial spirit is transforming the public sector. New York: Penguin Books.

Osborne, D., \& Plastik, P. (2000). The reinvestor's fielbook: Tools for transforming your government. San Francisco, CA: Jossey Bass.

Paolo, B., Silvana, S., \& Valerio, B. (2016). The Popular Financial Reporting: Focus on Stakeholders-The first European Experience. International Journal of Business and Management, 11(11), 115-125. https://doi.org/10.5539/ijbm.v11n11p115

Paris, V., Devaux, M., \& Wei, L. (2010). Health institutional characteristics: a survey of 29 OECD countries. OECD Health Working Papers, (50).

Pica, F., \& Villani, S. (2010). Issues regarding the standard cost notion: patients' interregional mobility and health fashions (No. 29659). University Library of Munich, Germany.

Postman, N. (1979). Teaching as a conserving activity. New York, NY: Delacorte Press.

Postman, N. (1985). Amusing ourselves to death: Public discourse in the age of show business. New York, NY: Viking.

Retzlaff-Roberts, D., Chang, C. F., \& Rubin, R. M. (2004). Technical efficiency in the use of health care resources: a comparison of OECD countries. Health Policy, 69(1), 55-72. https://doi.org/10.1016/j.healthpol.2003.12.002

Ricci, P. (Ed.). (2005). Enti strumentali regionali e loro accountability: il caso Campania (Vol. 350). Milan: FrancoAngeli.

Semenak, S. (1995, December 28). Feeling right at home: Government residence eschews traditional rules. Montreal Gazette, A4.

Strong, E. K. Jr., \& Uhrbrock, R. S. (1923). Bibliography on job analysis. In L. Outhwaite (Series Ed.), Personnel Research Series: Vol. 1. Job analysis and the curriculum (pp. 140-146). https://doi.org/10.1037/10762-000

United Nation. (2007). World Population Prospects: the 2017 Revision. Retrieved from https://esa.un.org/unpd/wpp/Publications/Files/WPP2017_KeyFindings.pdf

Vogel, J. (1999). The European 'welfare mix': institutional configuration and distributive outcome in Sweden and the European Union. A Longitudinal and Comparative Perspective. Social Indicators Research, 48(3), 245-296.

World Health Organization. (2010). The world health report, health systems financing, the path to universal coverage.

Yusuf, J. E., Jordan, M. M., Neill, K. A., \& Hackbart, M. (2013). For the people: Popular financial reporting practices of local governments. Public Budgeting \& Finance, 33(1), 95-113. https://doi.org/10.1111/j.1540-5850.2013.12003.x 


\section{Appendix A}

Table 1. Mobility and variables for 2014

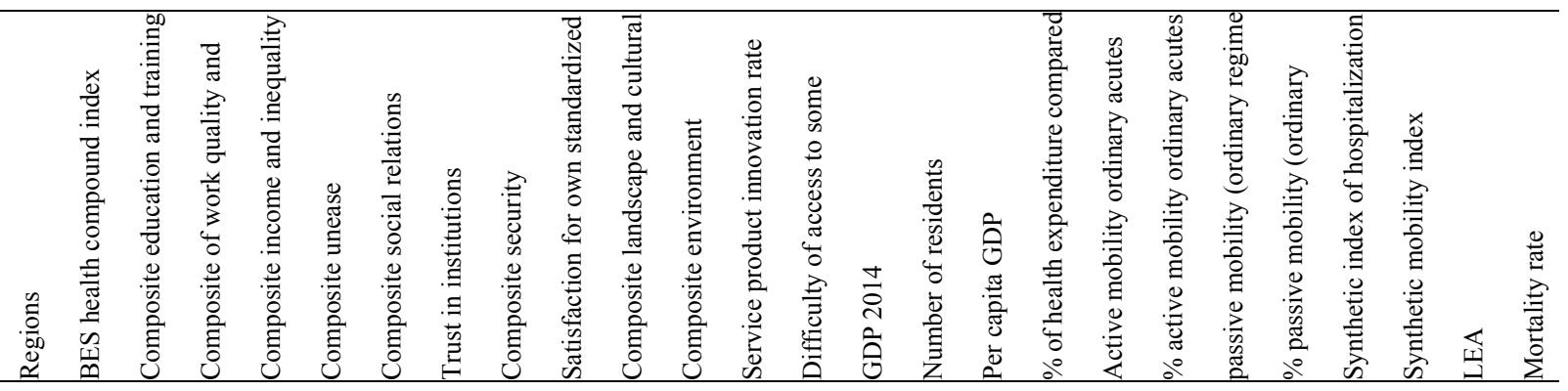

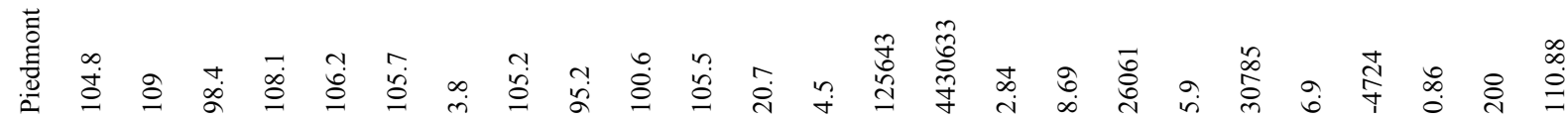

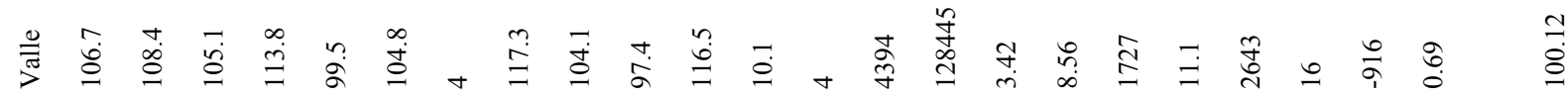

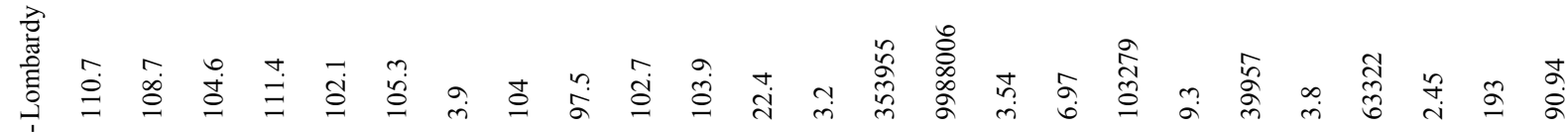

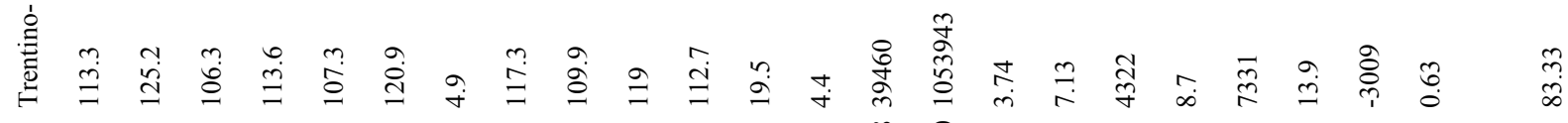

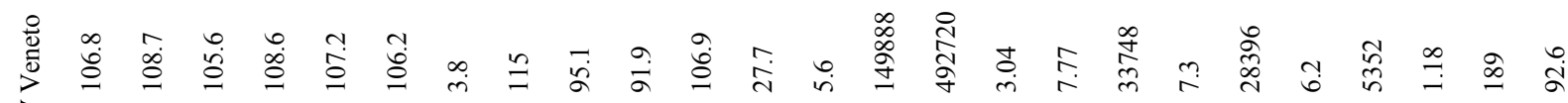

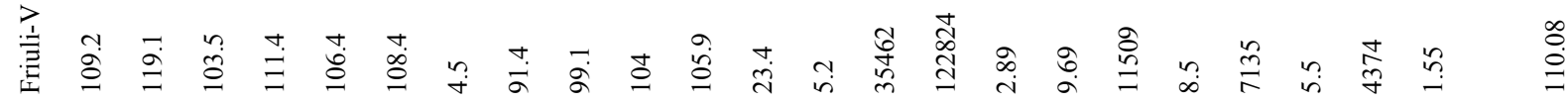

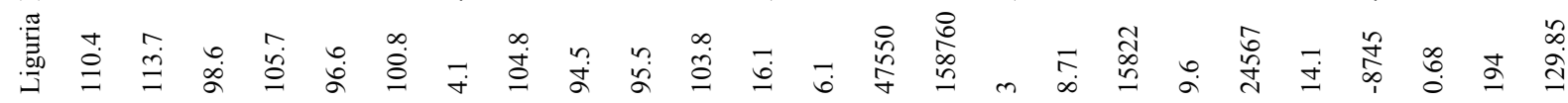

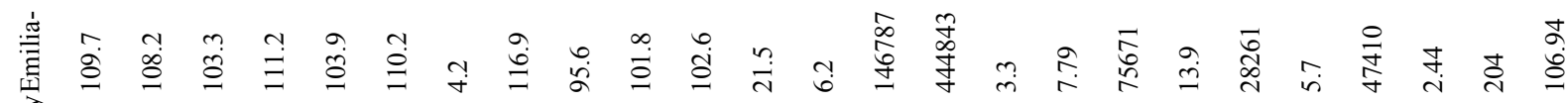

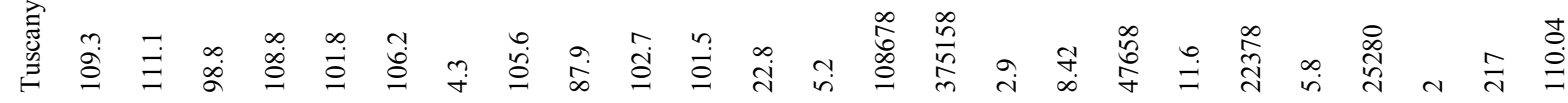
愛

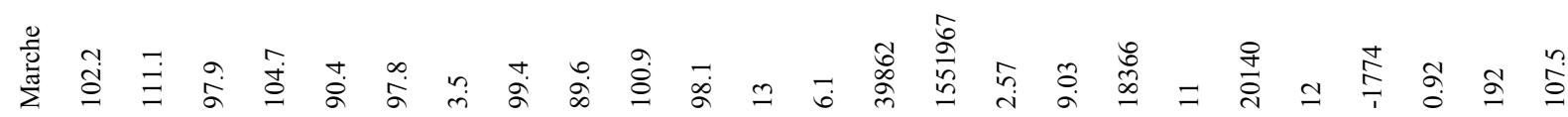

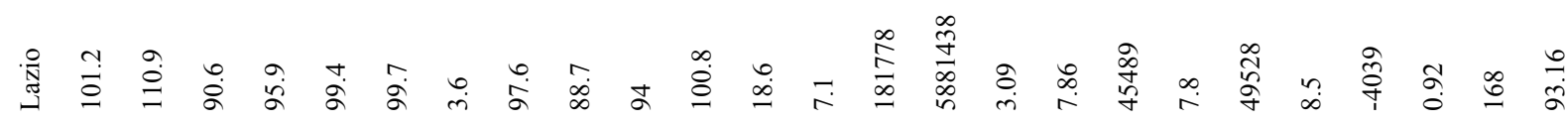

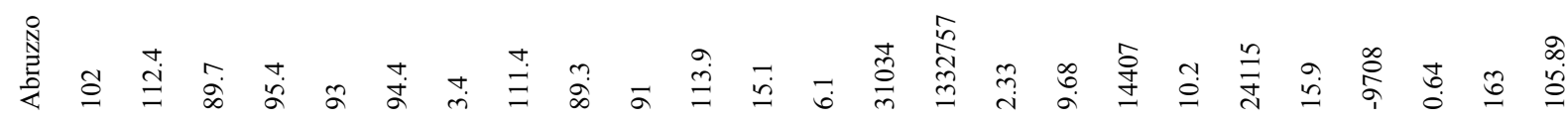

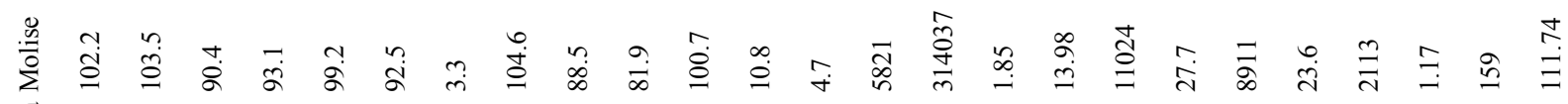
愛

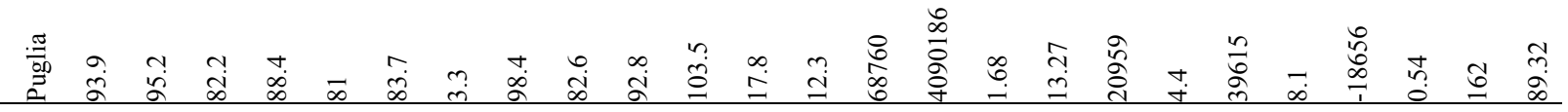




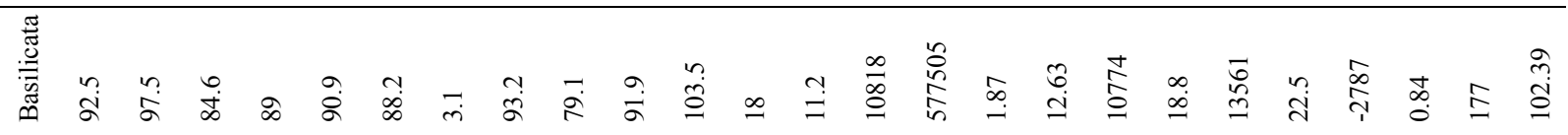

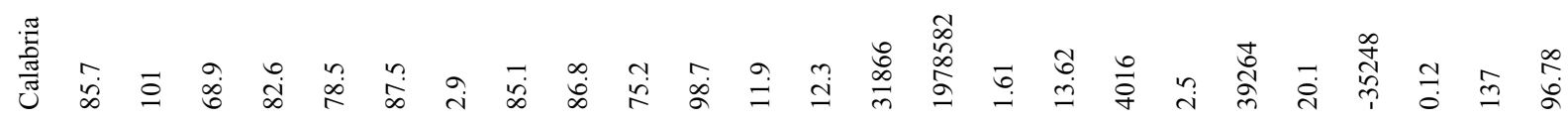

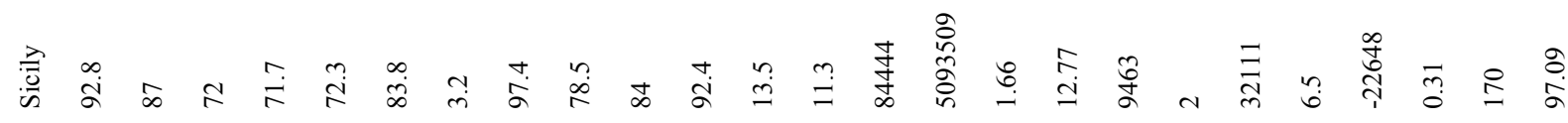

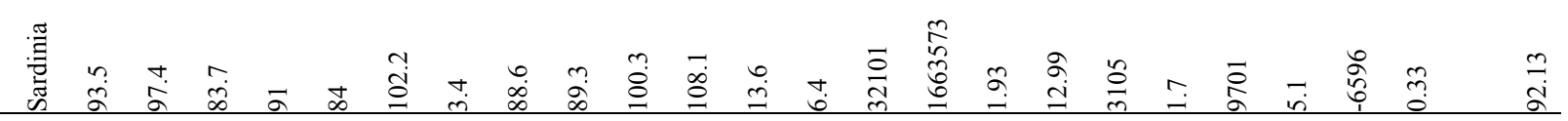

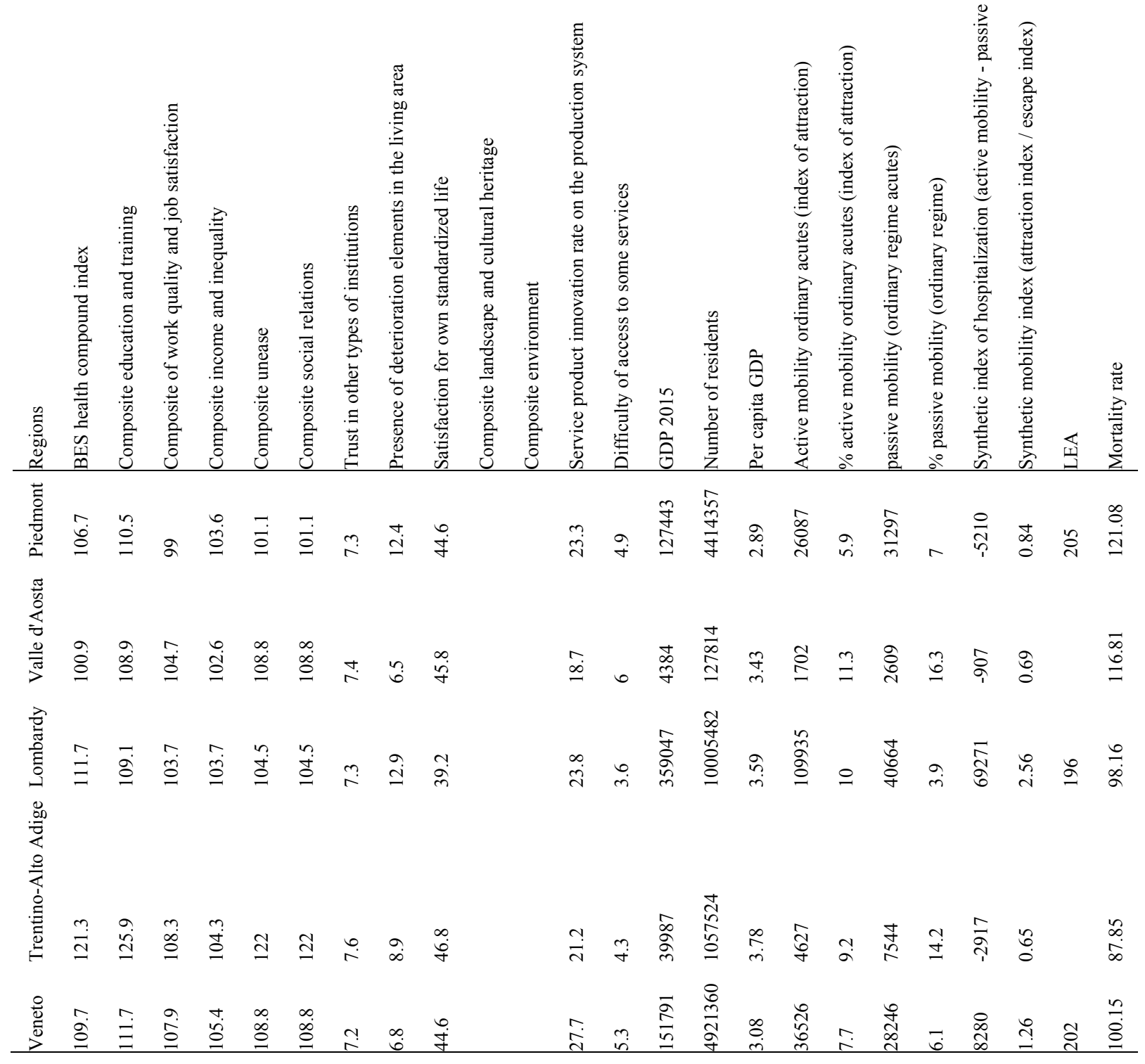


莺

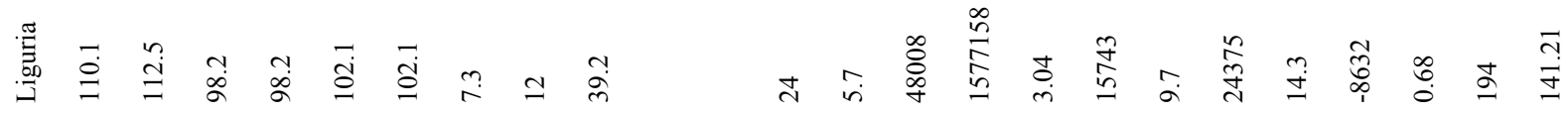

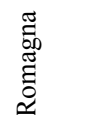

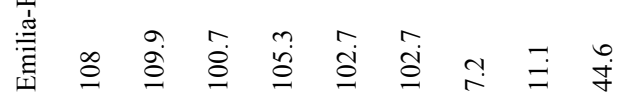

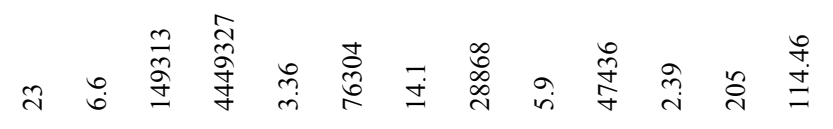

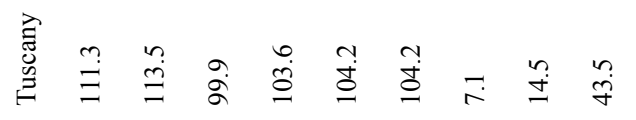
茫

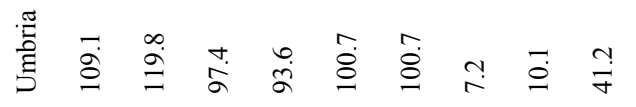

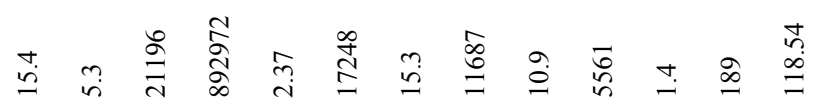

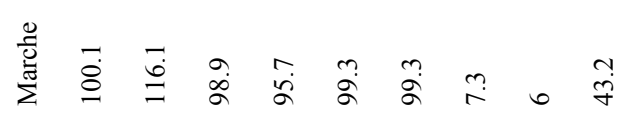

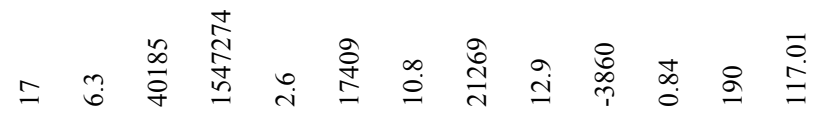

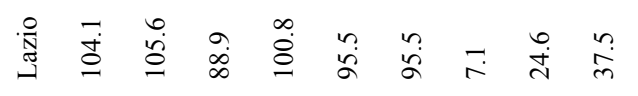

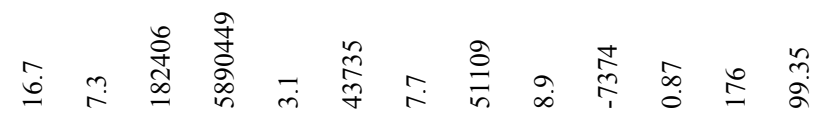
产

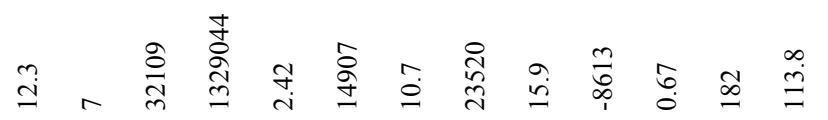

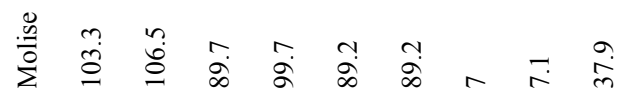

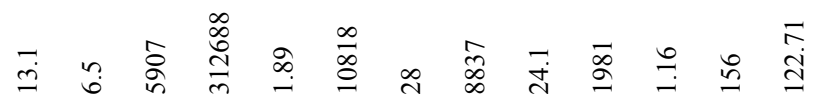
紕

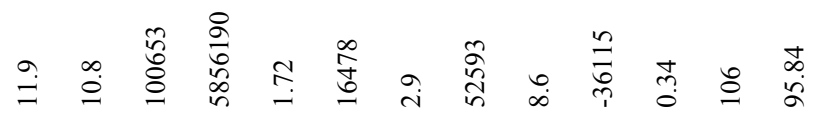

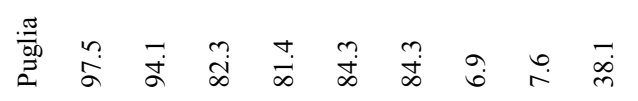

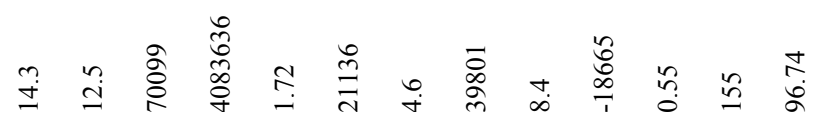

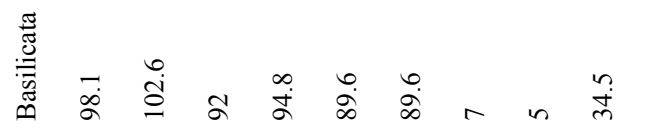

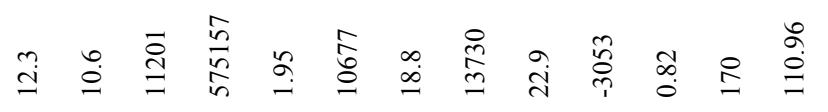
焉

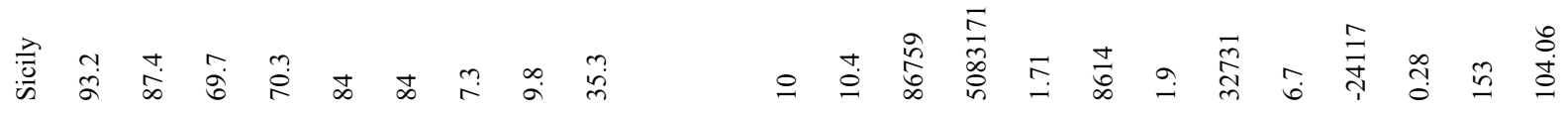

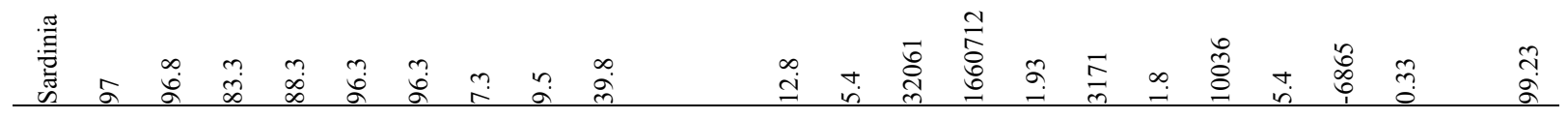




\begin{tabular}{|c|c|c|c|c|c|c|c|c|c|c|c|c|c|c|c|c|c|c|c|c|c|c|}
\hline 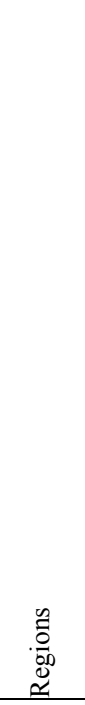 & 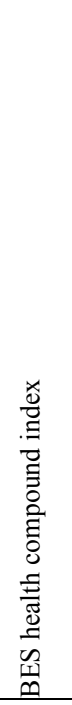 & 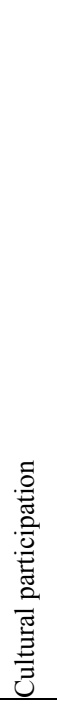 & 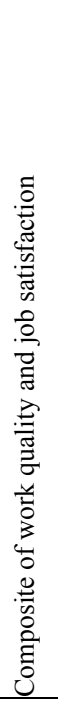 & 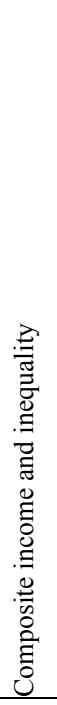 & 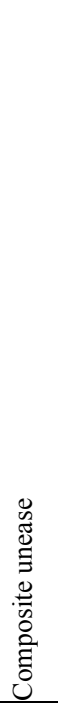 & 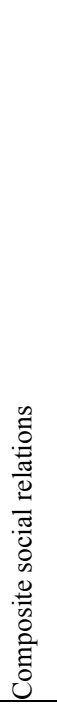 & 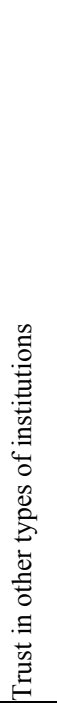 & 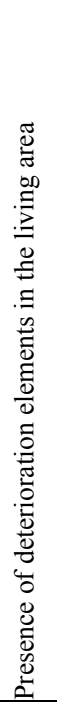 & 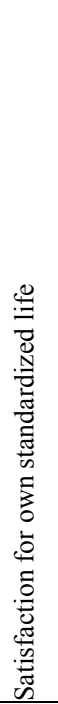 & 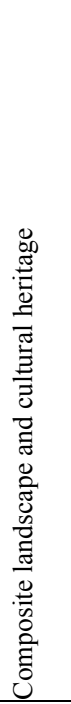 & 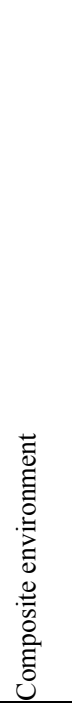 & 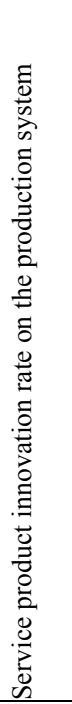 & 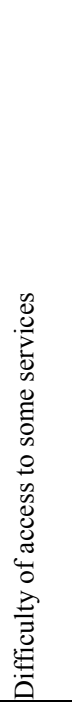 & 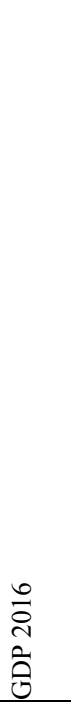 & 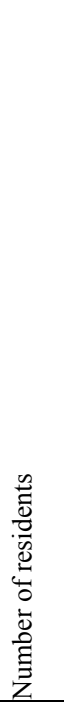 & 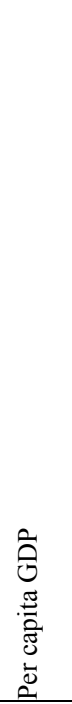 & 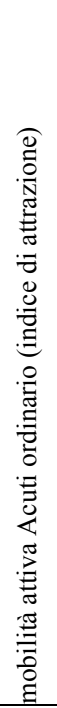 & 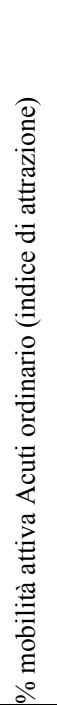 & 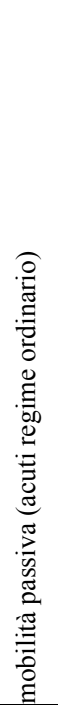 & 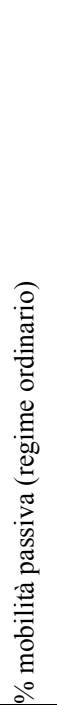 & 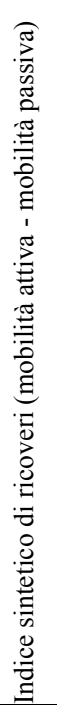 & 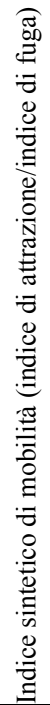 \\
\hline 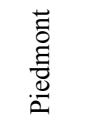 & & $\stackrel{i}{\dot{m}}$ & $\stackrel{n}{r}$ & $\stackrel{\infty}{+}$ & & & $\stackrel{m}{r}$ & $\simeq$ & $\begin{array}{l}\stackrel{0}{+} \\
\dot{+}\end{array}$ & & & & $\stackrel{\vec{n}}{\dot{n}}$ & & 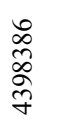 & & 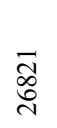 & તૃ & $\begin{array}{l}\vec{\nabla} \\
\stackrel{\infty}{0} \\
0\end{array}$ & $\vec{r}$ & ஜ̊ & $\begin{array}{c}\infty \\
0 \\
0\end{array}$ \\
\hline 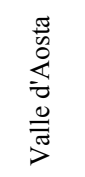 & & $\hat{i}$ & $\stackrel{i}{r}$ & $\stackrel{\odot}{+}$ & & & $\stackrel{+}{r}$ & : & $\begin{array}{l}\infty \\
\dot{y}\end{array}$ & & & & $\stackrel{?}{?}$ & & 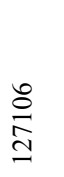 & & $\stackrel{\infty}{\widehat{\delta}}$ & $\stackrel{\circ}{\stackrel{\Xi}{\exists}}$ & $\stackrel{\infty}{\sim}$ & $\stackrel{\infty}{ \pm}$ & 常 & $\stackrel{\infty}{\stackrel{\infty}{0}}$ \\
\hline 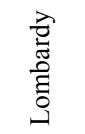 & & $\overrightarrow{\dot{m}}$ & 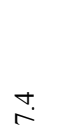 & in & & & $\stackrel{m}{r}$ & 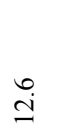 & $\begin{array}{l}\infty \\
\dot{f} \\
\dot{f}\end{array}$ & & & & $\bar{F}$ & & $\begin{array}{l}\stackrel{\infty}{o} \\
\stackrel{n}{n} \\
\stackrel{0}{0}\end{array}$ & & $\stackrel{\infty}{\stackrel{\circ}{n}}$ & $\stackrel{\stackrel{\circ}{\circ}}{\circ}$ & 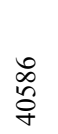 & t & 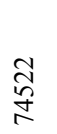 & 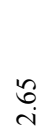 \\
\hline 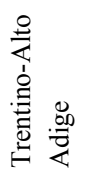 & & $\begin{array}{l}0 \\
\dot{\sigma}\end{array}$ & $\stackrel{\infty}{\stackrel{\infty}{\sim}}$ & $\stackrel{\circ}{+}$ & & & $\stackrel{\circ}{\stackrel{2}{*}}$ & $\underset{\infty}{\infty}$ & $\begin{array}{l}\infty \\
\stackrel{\circ}{\circ}\end{array}$ & & & & $\stackrel{n}{n}$ & & $\begin{array}{l}\text { के } \\
\text { Oे } \\
\stackrel{0}{0}\end{array}$ & & $\begin{array}{l}\vec{\infty} \\
\stackrel{\sigma}{\sigma}\end{array}$ & $\hat{a}$ & $\stackrel{\infty}{\infty}$ & $\because$ & 令 & : \\
\hline 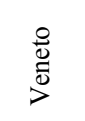 & & $\frac{\partial}{m}$ & $\stackrel{n}{\sim}$ & $\stackrel{?}{+}$ & & & $\stackrel{\Upsilon}{\curvearrowright}$ & oे & $\begin{array}{l}\circ \\
\stackrel{+}{+}\end{array}$ & & & & $\overrightarrow{6}$ & & $\begin{array}{l}\stackrel{0}{7} \\
\stackrel{\vec{q}}{\vec{\sigma}}\end{array}$ & & $\underset{\substack{\infty \\
\infty}}{\infty}$ & $\infty$ & $\frac{\text { ले }}{\text { ন }}$ & $\overrightarrow{6}$ & 㕝 & $\vec{m}$ \\
\hline 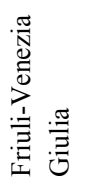 & & 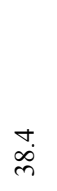 & $\stackrel{?}{r}$ & $\bar{F}$ & & & $\stackrel{n}{r}$ & ঙั & $\begin{array}{l}\dot{\nabla} \\
\dot{q}\end{array}$ & & & & in & & 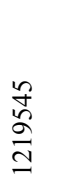 & & $\stackrel{\sim}{\varrho}$ & $\begin{array}{l}\infty \\
\infty \\
\infty\end{array}$ & $\begin{array}{l}+\begin{array}{c}+ \\
\vdots \\
\infty\end{array} \\
\end{array}$ & $n$ & స్స & $\stackrel{m}{\rightarrow}$ \\
\hline 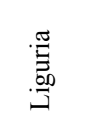 & & $\begin{array}{l}\text { : } \\
\stackrel{\sim}{ }\end{array}$ & $\stackrel{?}{r}$ & n? & & & $\stackrel{?}{r}$ & $\stackrel{\Xi}{\Xi}$ & ஸે & & & & in & & $\begin{array}{l}\infty \\
\stackrel{\infty}{\infty} \\
\stackrel{0}{n} \\
\stackrel{n}{n}\end{array}$ & & $\begin{array}{l}\text { ڤั } \\
\stackrel{2}{n}\end{array}$ & $\overrightarrow{0}$ & $\begin{array}{l}\stackrel{7}{~} \\
\text { 心 }\end{array}$ & $\stackrel{m}{n}$ & ò & \begin{tabular}{l}
$\stackrel{0}{0}$ \\
\hdashline
\end{tabular} \\
\hline 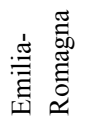 & & $\overrightarrow{\dot{m}}$ & $\stackrel{⿱ 亠}{r}$ & $\underset{+}{\circ}$ & & & $\stackrel{\leftrightarrow}{r}$ & $\grave{\varrho}$ & $\begin{array}{l}\stackrel{0}{+} \\
\dot{f}\end{array}$ & & & & $\stackrel{i}{i}$ & & $\begin{array}{l}\text { 芓 } \\
\text { 京 } \\
\text { 京 }\end{array}$ & & $\begin{array}{l}\infty \\
\stackrel{0}{0} \\
\stackrel{2}{2}\end{array}$ & $\stackrel{m}{ \pm}$ & $\begin{array}{l}\tilde{\hat{~}} \\
\text { సे }\end{array}$ & 6 & $\begin{array}{l}\text { W } \\
\text { ò } \\
\text { d }\end{array}$ & $\stackrel{\infty}{i}$ \\
\hline 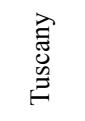 & & के & $\stackrel{⿱ 亠}{r}$ & F & & & $\stackrel{?}{?}$ & $\stackrel{n}{ \pm}$ & $\stackrel{\sim}{\dddot{q}}$ & & & & $\overrightarrow{6}$ & & $\begin{array}{c}\frac{\infty}{F} \\
\underset{m}{+} \\
\dot{m}\end{array}$ & & 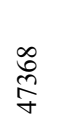 & $\simeq$ & $\begin{array}{l}\vec{n} \\
\stackrel{\sqrt{N}}{2}\end{array}$ & $\overrightarrow{6}$ & $\begin{array}{l}\text { Ta } \\
\text { d̦ }\end{array}$ & $\widehat{a}$ \\
\hline $\begin{array}{l}\text {. } \\
\text { है } \\
\text { है }\end{array}$ & & $\partial$ & †. & . & & & $=$ & $\overrightarrow{0}$ & $\stackrel{\Upsilon}{\rightleftarrows}$ & & & & ָุ & & 管 & & 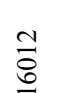 & $\vec{n}$ & 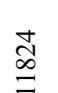 & $\stackrel{\circ}{=}$ & 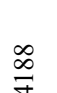 & \\
\hline
\end{tabular}




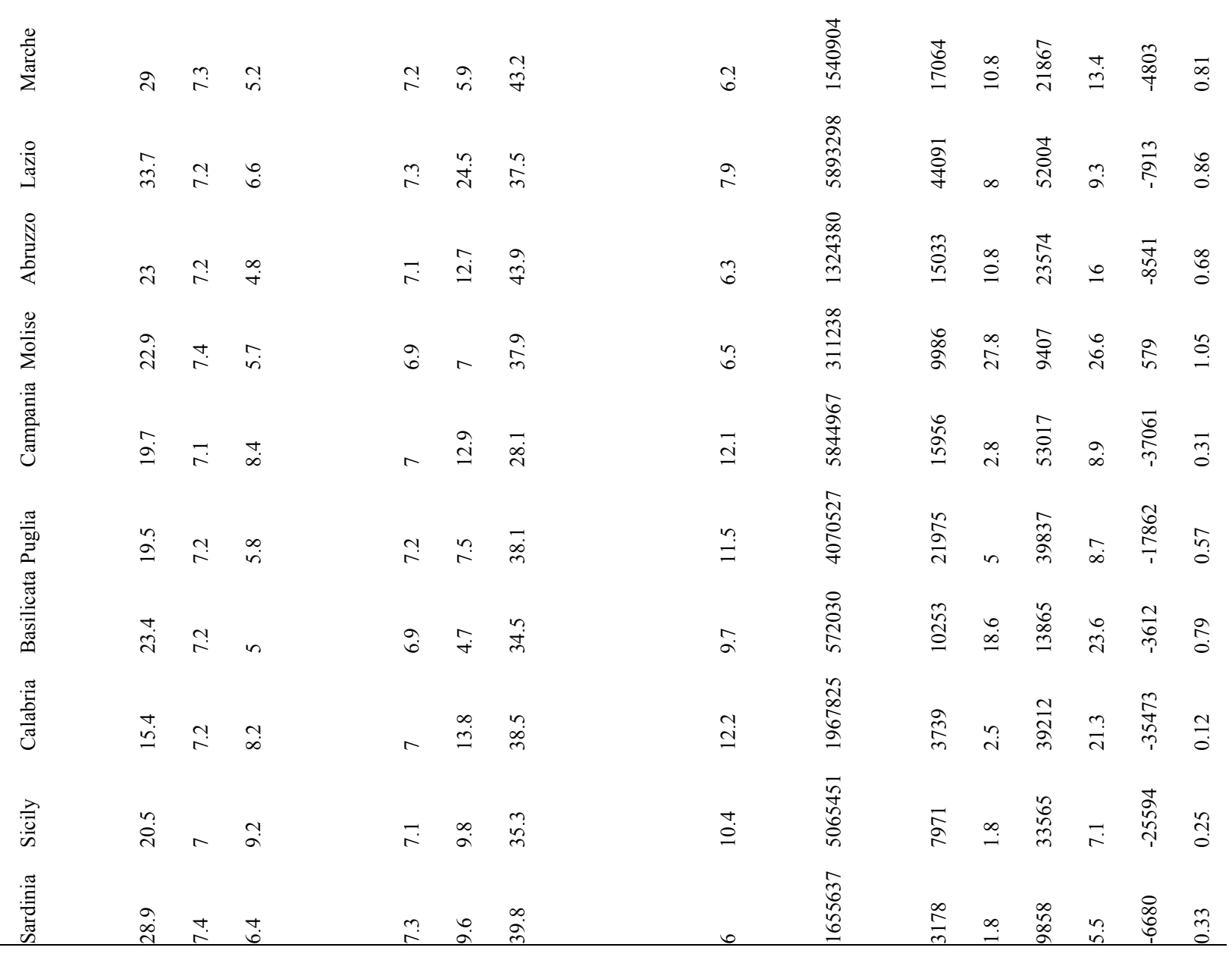

\section{Copyrights}

Copyright for this article is retained by the author, with first publication rights granted to the journal.

This is an open-access article distributed under the terms and conditions of the Creative Commons Attribution license (http://creativecommons.org/licenses/by/4.0/). 